Indian J Med Res 59, 2 February 1971 pp. 175-189

\title{
A Comparison Of Various Measures Of Sensitivity Of M. Tuberculosis To Pyrazinamide*
}

\author{
S. P. Tripathy D. A. Mitchison N.G.K. Nair S. Radhakrishna and S. Subbammal \\ Tuberculosis Chemotherapy Centre † M adras-31
}

Received for publication August 121970

\begin{abstract}
Information on the in vitro sensitivity of $\mathbf{M}$ ycobacterium tuberculosis to pyrazinamide is limited, mainly because of the difficulty in choosing an appropriate $\mathrm{pH}$ for the medium employed. A pyrazinamide sensitivity test, employing Lowenstein-Jensen medium acidified with hydrochloric acid to a preinspissation $\mathrm{pH}$ of $4.80-4.85$, was developed at this Centre, and performed on cultures from tuberculous patients. Sensitivity was measured as the minimal inhibitory concentration (MIC) of pyrazinamide for various sires of the inoculum, and as proportions of the bacterial population resistant to various concentrations of the drug. For each measure, the findings in patients with no history of previous chemotherapy with pyrazinamide were compared with those obtained at 4-12 months after the start of daily treatment with pyrazinamide ; the definition of resistance was chosen such that it discriminated efficiently between the two populations, and classified only a small proportion of the former population as resistant. Four definitions of resistance were chosen-an MIC of $200 \mu \mathrm{g} / \mathrm{ml}$ or more employing an inoculum containing approximately $0.4 \mathrm{mg}$ of bacilli per $\mathrm{ml}$ and a 10-colony end-point, and proportions of $20 \%$ or more on $25 \mu \mathrm{g} / \mathrm{ml}, 5 \%$ or more on $50 \mu \mathrm{g} / \mathrm{ml}$, and $1 \%$ or more on $100 \mu \mathrm{g} / \mathrm{ml}$. The four definitions were of similar efficiency. Employing them, it was found that wild strains with consistent resistance to pyrazinamide were rare in Madras patients ; also, in patients who received daily pyrazinamide, resistance emerged (if at all) at 4-6 months after the start of treatment.
\end{abstract}

\section{Introduction}

Pyrazinamide was first reported to have antituberculosis activity in the mouse (Kushner et al 1952, Malone et al 1952), but to be devoid of in vitro activity against Mycobacterium tuberculosis (Tarshis and Weed 1953, Schwartz and Moyer 1954, Steenken and Wolinsky 1954). Later studies revealed, however, that the drug did exert activity in vitro, but only in acid medium of $\mathrm{pH}$ 5.0-5.5 (McDermott and Tompsett 1954). Several acid media have since been used for pyrazinamide sensitivity tests (Canetti, Rist and Grosset 1963, Marks 1964, Stottmeier, Beam and Kubica 1967), but it has always been difficult to choose an appropriate $\mathrm{pH}$ for the medium such that pyrazinamide is active and as few as possible of the test strains are inhibited solely by the acidity of the medium. In consequence, there is limited information on the in vitro sensitivity

\footnotetext{
*This paper is also being published in the Tubercle

$\dagger$ The Centre is under the joint auspices of the Indian Council of Medical Research, the Tamil Nadu (Madras State) Government, and the World Health Organization in collaboration with the Medical Research Council of Great Britain
} 
of M. tuberculosis to pyrazinamide and on the emergence of pyrazinamide resistance during treatment with the drug.

In a preliminary study at this Centre, fluid acid media were found to be unsatisfactory since many strains of tubercle bacilli failed to grow in them. Three solid mediaSteenken and Smith's acid medium (United States Veterans Administration 1960) Lowenstein-Jensen medium acidified with hydrochloric acid and Lowenstein-Jensen medium acidified with citric acid were, therefore, compared for their ability to sustain the growth of tubercle bacilli ; all three media had a pre-inspissation $\mathrm{pH}$ of 5.1 and a post-inspissation $\mathrm{pH}$ of 5.4-5.5. It was found that the Lowenstein-Jensen medium acidified with hydrochloric acid yielded the most satisfactory growth of tubercle bacilli. Furthermore, this medium, at its normal $\mathrm{pH}$, is employed for all other drug sensitivity tests at this Centre. Therefore, further experimentation was restricted to the Lowenstein-Jensen medium acidified with hydrochloric acid. A comparative study of this medium at three $\mathrm{pH}$ levels, namely 4.80, 4.95 and 5.10 showed that the $\mathrm{pH}$ of 4.80 was the best, in terms of demonstrating the activity of the drug and sustaining the growth of tubercle bacilli. For all subsequent tests the medium employed had a pre-inspissation $\mathrm{pH}$ of 4.80-4.85.

The present report is based on the findings of pyrazinamide sensitivity tests undertaken at this Centre since 1963, and compares the relative efficiency of various measures of sensitivity (minimal inhibitory concentrations, proportions resistant) in detecting resistance to pyrazinamide ; an interim report was presented earlier (Tripathy 1966).

\section{Material and Methods}

Strains : The following cultures of M. tuberculosis were tested :

Wild (W) cultures : A pair of cultures, obtained before the start of chemotherapy, from each of 222 newly-diagnosed tuberculous patients admitted to a chemotherapy study at this Centre. All the cultures were sensitive to isoniazid and streptomycin according to standard definitions (Tuberculosis Chemotherapy Centre Madras 1959). For all analyses other than the one on variation between duplicate cultures, only the results on the first culture from each patient have been considered.

Failure (F) cultures : Cultures from patients who were treatment failures of one or more regimens not including pyrazinamide, at this Centre. Over a period of one year, 51 such cultures were tested from the same number of patients, and of these, 34 were resistant to isoniazid.

Probably resistant (PR) cultures : Cultures isolated from patients during treatment (1-12 months) with regimens containing pyrazinamide in a single daily dose of 1.0 to $1.5 \mathrm{~g}$. In all, 154 cultures were obtained from 55 such patients (all of them were treatment failures of one or more regimens at this Centre), and tested over the same period as the $\mathrm{F}$ cultures.

British cultures : A sample of 25 cultures, obtained before the start of chemotherapy, from the same number of British patients with newly-diagnosed pulmonary 
tuberculosis. The sample was obtained by random selection from cultures sensitive to isoniazid and streptomycin (according to standard definitions) in a national survey of the prevalence of drug resistance in Britain (Miller et al 1966).

H37Rv : The sensitivity of the standard strain, H37Rv, was determined in each batch of pyrazinamide medium, the total number of tests was 86 .

Medium and drug concentrations : Acidified Lowenstein-Jensen medium with a preinspissation $\mathrm{pH}$ of 4.80-4.85 was employed. This was prepared by mixing the basic ingredients of Lowenstein-Jensen medium (Cruickshank 1965), and adding approximately $20 \mathrm{ml}$ of $2 \mathrm{~N}$ hydrochloric acid per litre of the medium ; the $\mathrm{pH}$ was then adjusted employing a $\mathrm{pH}$ meter with a glass electrode.

The concentrations of pyrazinamide employed were $12.5,25,50$ and $100 \mu \mathrm{g} / \mathrm{ml}$. Both the drug-containing medium and the drug-free (control) medium were distributed in $7 \mathrm{ml}$ quantities in $1 \mathrm{oz}$ screw-capped Universal containers and inspissated at $85^{\circ} \mathrm{C}$ for $50 \mathrm{~min}$. The $\mathrm{pH}$ of the medium after inspissation ranged from 5.10 to 5.20.

Lowenstein-Jensen medium at its normal pH (6.8 to 7.0) was also employed, in order to determine the effect of acidification of the medium on the growth of the strains. Sensitivity tests: The sensitivity tests were of the indirect type and were undertaken on the primary isolates in the case of the W, F and PR strains, and on subcultures in the case of the H37Rv and British strains. Approximately $4 \mathrm{mg}$ (moist weight) of growth, as judged by eye, was taken with a 22-SWG nichrome loop and placed in a $4 \mathrm{oz}$ screw-capped bottle containing $123-\mathrm{mm}$ diameter glass beads and $0.2 \mathrm{ml}$ distilled water. After shaking the bottle for $1 \mathrm{~min}, 0.8 \mathrm{ml}$ distilled water was added to obtain a suspension containing approximately $4 \mathrm{mg}$ of bacilli per $\mathrm{ml}\left(\mathrm{S}_{1}\right)$. Four successive 10 -fold dilutions $\left(\mathrm{S}_{2}, \mathrm{~S}_{3}, \mathrm{~S}_{4}\right.$ and $\left.\mathrm{S}_{5}\right)$ were then prepared by adding appropriate amounts of distilled water. One loopful (27 SWG nichrome, 3-mm external diameter) from each of the suspensions, $\mathrm{S}_{1}, \mathrm{~S}_{2}, \mathrm{~S}_{3}$ and $\mathrm{S}_{4}$ inoculated on to slopes containing pyrazinamide $12.5,25,50$ and $100 \mu \mathrm{g} / \mathrm{ml}$ (Table I). As controls, one drug-free acidified Lowenstein-Jensen slope was inoculated with the suspension $S_{1}$, one with the suspension $S_{2}$ and 2 each with the suspensions $S_{3}, S_{4}$ and $S_{5}$. Drug-free slopes of normal LowensteinJensen medium were also set up in parallel as further controls.

Particular care was taken not to dig the loop below the surface of the soft acid medium, and not to inoculate into the water of condensation or on to the medium immediately adjoining the glass surface. The slopes were incubated at $37^{\circ} \mathrm{C}$ and examined 40 days later.

The minimal concentrations of the drug inhibiting growth (MICs) on slopes inoculated with suspensions $\mathrm{S}_{1}, \mathrm{~S}_{2}$ and $\mathrm{S}_{3}$ were determined. For this purpose, growth was defined as the appearance of 20 or more colonies on slopes inoculated with the $S_{1}$ suspension 10 or more colonies with the $S_{2}$ suspension and 5 or more colonies with the $\mathrm{S}_{3}$ suspensions (If there was growth on the $100 \mu \mathrm{g} / \mathrm{ml}$ pyrazinamide slope-the highest concentration employed in this study-the MIC was regarded as $200 \mu \mathrm{g} / \mathrm{ml}$ or more). 
Table I. An example of the findings of the pyrazinamide sensitivity test*

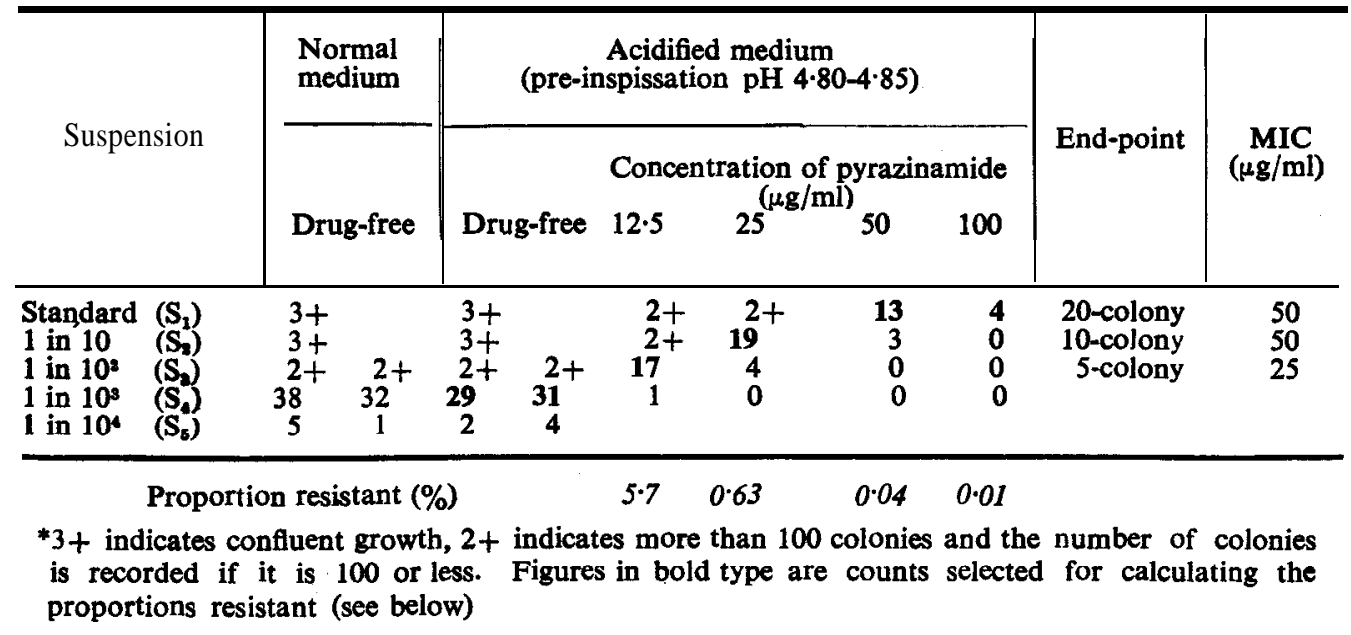

Next, the proportions of the bacterial population resistant to different concentrations of pyrazinamide $(12.5,25,50$ and $100 \mu \mathrm{g} / \mathrm{ml})$ were determined. For this purpose, the number of colonies on the drug-containing slope inoculated with the $S_{1}$ suspension was estimated, and expressed as a percentage of the estimated number of colonies on the acidified drug-free $\mathrm{S}_{1}$ slope. The counts selected for estimation purposes were, in the order of preference, 20-70, 5-19 and more than 70 colonies on the drug-free slopes (the mean count was considered for the $S_{3}, S_{4}$ and $S_{5}$ suspensions), and 5-100, 0-4 and more than 100 colonies on the drug-containing slopes. If more than one suspension yielded satisfactory counts with the drug-containing medium, the count on the suspension closest to the one selected for estimating the bacterial population on the drug-free $S_{1}$ slope was chosen. When the satisfactory count was zero with the drug-containing medium, the proportion resistant was calculated assuming that one colony grew on the heaviest of the suspensions with the zero colony count (usually $S_{1}$ ) and the result expressed as less than this proportion. When classifying individual cultures as sensitive or resistant, such a result was excluded from the analysis if the proportion was higher than the critical proportion signifying resistance.

An example of the findings of the pyrazinamide sensitivity test is set out in Table I, together with the various measures of sensitivity derived from them.

\section{Results}

Growth on acidified drug-free medium : Of 538 cultures that grew on normal drug-free medium, only 4 failed to grow on acidified drug-free medium (Table II). Considering the remaining 534 cultures, the growth on the acidified medium was less than $50 \%$ of the growth on the normal medium for $147(28 \%)$. Finally, the mean viable 
count in the acidified medium $\left(1.2 \times 10^{4}\right)$ was appreciably less than that in the normal medium $\left(2.0 \times 10^{4}\right)$.

Table II. Comparison of growth on normal and acidified drug-free Lowenstein-Jensen medium

\begin{tabular}{|c|c|c|c|c|c|c|c|}
\hline \multirow{3}{*}{$\begin{array}{l}\text { Type of } \\
\text { culture }\end{array}$} & \multirow{3}{*}{$\begin{array}{l}\text { Cultures with } \\
\text { no growth on } \\
\text { acidified } \\
\text { medium }\end{array}$} & \multicolumn{6}{|c|}{ Cultures with growth on acidified medium } \\
\hline & & \multirow{2}{*}{ Total } & \multicolumn{3}{|c|}{$\begin{array}{l}\text { Growth on acidified medium } \\
\text { expressed as a percentage of } \\
\text { growth on normal medium }\end{array}$} & \multicolumn{2}{|c|}{ Mean viable count } \\
\hline & & & $\begin{array}{l}\text { Less } \\
\text { than } 10\end{array}$ & $10-50-$ & $\begin{array}{l}100 \text { or } \\
\text { more }\end{array}$ & $\begin{array}{l}\text { Acidified } \\
\text { medium }\end{array}$ & $\begin{array}{l}\text { Normal } \\
\text { medium }\end{array}$ \\
\hline $\begin{array}{l}\text { Madras W } \\
\text { Madras F } \\
\text { Madras PR } \\
\text { British } \\
\text { H37Rv }\end{array}$ & $\begin{array}{l}0 \\
2 \\
0 \\
2 \\
0\end{array}$ & $\begin{array}{r}222 \\
49 \\
154 \\
23 \\
86\end{array}$ & $\begin{array}{r}17 \\
7 \\
22 \\
7 \\
4\end{array}$ & $\begin{array}{r}26 \\
4 \\
26 \\
4 \\
30\end{array}$ & $\begin{array}{r}105 \\
23 \\
66 \\
2 \\
14\end{array}$ & $\begin{array}{l}1.8 \times 10^{4} \\
1.1 \times 10^{4} \\
1.0 \times 10^{4} \\
0.4 \times 10^{4} \\
0.8 \times 10^{4}\end{array}$ & $\begin{array}{l}2.5 \times 10^{4} \\
1.7 \times 10^{4} \\
1.8 \times 10^{4} \\
1.8 \times 10^{4} \\
1.6 \times 10^{4}\end{array}$ \\
\hline All cultures & 4 & 534 & 57 & 177 & 210 & $1.2 \times 10^{4}$ & $2.0 \times 10^{4}$ \\
\hline
\end{tabular}

Considering pre-treatment strains, there was evidence that British cultures grew less well than Madras 'cultures, especially in acidified medium. Thus, the mean viable count in normal medium was $1.8 \times 10^{4}$ for the British and $2.5 \times 10^{4}$ for the Madras cultures, and the corresponding mean counts in acidified medium were $0.4 \times 10^{4}$ and $1.8 \times 10^{4}$, respectively. Lastly, the growth on the acidified medium was $50 \%$ or more of the growth on the normal medium for $12(48 \%)$ of 25 British cultures as compared with $179(81 \%)$ of 222 Madras cultures, a highly significant difference $(\mathrm{P}<0.001)$.

Sensitivity, expressed as an MIC, of different types of cultures : It will be recalled that the W, F and British cultures were all isolated from patients who had no history of previous chemotherapy with pyrazinamide, and that the PR cultures were obtained from patients at 1-12 months after the start of treatment with daily pyrazinamide. Therefore, the former group would have consisted predominantly of pyrazinamide-sensitive cultures while the latter is likely to have included an appreciable proportion of pyrazinamide-resistant cultures.

Table III sets out the cumulative distributions of various types of cultures accord, ing to the $\mathrm{S}_{1}$-MIC, the $\mathrm{S}_{2}$-MIC and the $\mathrm{S}_{3}$-MIC. The total number of results available is slightly smaller than the number of tests set up, partly because of contamination but mainly due to the growth on the control slopes being insufficient for determining the MIC. In all, the $\mathrm{S}_{1}$-MIC could not be determined for $8(1.5 \%)$ of 534 cultures tested, the $\mathrm{S}_{2}$-MIC for 19(3.6\%) and the $\mathrm{S}_{3}$-MIC for $41(7.7 \%)$ cultures.

In general, the $\mathrm{W}$ cultures and $\mathrm{F}$ cultures had similar distributions. The amalgamated group of cultures $(\mathrm{W}+\mathrm{F})$, however, was less sensitive than the British cultures and the strain H37Rv. For instance, $83 \%$ of $268 \mathrm{~W}+\mathrm{F}$ cultures had an $\mathrm{S}_{1}-\mathrm{MIC}$ of 
Table III. Cumulative distribution of cultures according to minimal inhibitory concentrations at $\mathbf{4 0}$ days

\begin{tabular}{|c|c|c|c|c|c|c|c|c|c|c|c|}
\hline \multirow{2}{*}{$\begin{array}{l}\text { Suspension } \\
\text { and } \\
\text { end-point }\end{array}$} & \multirow{2}{*}{$\underset{(\mu \mathrm{g} / \mathrm{ml})}{\mathrm{MIC}}$} & \multicolumn{5}{|c|}{ No chemotherapy with pyrazinamide } & \multicolumn{4}{|c|}{$\begin{array}{l}\text { Duration (months) of chemotherapy } \\
\text { with pyrazinamide } \\
\text { (PR cultures) }\end{array}$} & \multirow{2}{*}{$\begin{array}{l}\text { Measure of } \\
\text { discrimination } \\
(b-a)\end{array}$} \\
\hline & & $\begin{array}{c}\text { H37Rv } \\
(\%)\end{array}$ & $\begin{array}{c}\text { British } \\
(\%)\end{array}$ & $\begin{array}{l}W \\
(\%)\end{array}$ & $\begin{array}{l}F \\
(\%)\end{array}$ & $\underset{(\%)}{W}+F$ & $(\%)^{3}$ & $\begin{array}{c}4 \% \\
(\%)\end{array}$ & $\begin{array}{l}+-12 \\
(\%)\end{array}$ & $\begin{array}{c}4-12 \\
(\%)(b)\end{array}$ & \\
\hline \multirow[t]{2}{*}{$20 \stackrel{S_{1}}{\text { colony }}$} & $\begin{array}{l}25 \text { or more } \\
50 \text { or more } \\
100 \text { or more } \\
200 \text { or more }\end{array}$ & $\begin{array}{l}62 \\
39 \\
25 \\
14\end{array}$ & $\begin{array}{r}57 \\
24 \\
\quad 14 \\
\quad 10\end{array}$ & $\begin{array}{r}85 \\
\quad 58 \\
: \quad 36 \\
\times \quad 20\end{array}$ & $\begin{array}{l}77 \\
50 \\
35 \\
17\end{array}$ & $\begin{array}{l}83 \\
57 \\
36 \\
19\end{array}$ & $\begin{array}{l}74 \\
49 \\
40 \\
26\end{array}$ & $\begin{array}{l}86 \\
76 \\
69 \\
59\end{array}$ & $\begin{array}{l}94 \\
82 \\
65 \\
55\end{array}$ & $\begin{array}{l}90 \\
79 \\
67 \\
57\end{array}$ & $\begin{array}{r}7 \\
22 \\
31 \\
38\end{array}$ \\
\hline & No. of cultures & 84 & 21 & 220 & 48 & 268 & 53 & 51 & 49 & 100 & \\
\hline \multirow[t]{2}{*}{$10-S_{2}$} & $\begin{array}{l}25 \text { or more } \\
50 \text { or more } \\
100 \text { or more } \\
200 \text { or more }\end{array}$ & $\begin{array}{r}38 \\
16 \\
10 \\
4\end{array}$ & $\begin{array}{r}24 \\
14 \\
10 \\
5\end{array}$ & $\begin{array}{r}68 \\
\quad 33 \\
16 \\
9\end{array}$ & $\begin{array}{r}65 \\
37 \\
15 \\
2\end{array}$ & $\begin{array}{r}68 \\
34 \\
16 \\
8\end{array}$ & $\begin{array}{r}58 \\
31 \\
23 \\
8\end{array}$ & $\begin{array}{l}85 \\
69 \\
54 \\
52\end{array}$ & $\begin{array}{l}79 \\
62 \\
52 \\
44\end{array}$ & $\begin{array}{r}82 \\
\cdots . \quad 66 \\
53 \\
48\end{array}$ & $\begin{array}{l}14 \\
32 \\
37 \\
40\end{array}$ \\
\hline & No. of cultures & 81 & 21 & 219 & 46 & 265 & 52 & 48 & 48 & 96 & \\
\hline \multirow[t]{2}{*}{$\begin{array}{l}\mathrm{S}_{3} \\
5-\text { colony }\end{array}$} & $\begin{array}{l}25 \text { or more } \\
50 \text { or more } \\
100 \text { or more } \\
200 \text { or more }\end{array}$ & $\begin{array}{r}19 \\
11 \\
8 \\
5\end{array}$ & $\begin{array}{r}20 \\
13 \\
13 \\
0\end{array}$ & $\begin{array}{r}51 \\
14 \\
\vdots \quad 8 \\
\quad 3\end{array}$ & $\begin{array}{c}45 \\
20 \\
9 \\
0\end{array}$ & $\begin{array}{r}50 \\
15 \\
9 \\
2\end{array}$ & $\begin{array}{r}37 \\
18 \\
10 \\
8\end{array}$ & $\begin{array}{l}81 \\
64 \\
53 \\
40\end{array}$ & $\begin{array}{l}70 \\
49 \\
47 \\
42\end{array}$ & $\begin{array}{l}76 \\
57 \\
50 \\
41\end{array}$ & $\begin{array}{l}26 \\
42 \\
41 \\
39\end{array}$ \\
\hline & No. of cultures & 80 & 15 & 213 & 44 & 257 & 51 & 47 & 43 & 90 & \\
\hline
\end{tabular}


$25 \mu \mathrm{g} / \mathrm{ml}$ or more as compared with $57 \%$ of 21 British cultures $(\mathrm{P}<0.01)$ and $62 \%$ of 84 tests on the strain H37Rv $(\mathrm{P}<0.01)$.

Considering next the PR cultures, those isolated at 1-3 months were of the same order of sensitivity as the $\mathrm{W}+\mathrm{F}$ cultures. However, PR cultures isolated at 4-6 months and 7-12 months were substantially less susceptible. For instance;48 \% of 96 PR cultures isolated at 4-12 months had an $\mathrm{S}_{2}$-MIC of $200 \mu \mathrm{g} / \mathrm{ml}$ or more as compared with $8 \%$ of $265 \mathrm{~W}+\mathrm{F}$ cultures $\left(\mathrm{P}<10^{-5}\right)$ and $8 \%$ of $52 \mathrm{PR}$ cultures isolated at $1-3$ months $\left(\mathrm{P}<10^{-5}\right)$.

The findings in $\mathrm{W}+\mathrm{F}$ cultures and PR cultures isolated at 4-12 months formed the basis for evolving definitions of pyrazinamide resistance in Madras Cultures.

Considerations involved in the choice of definitions of resistance: Two considerations were involved in the choice of definitions of resistance. These were (1) the definition should discriminate efficiently between the $\mathrm{W}+\mathrm{F}$ cultures on the one hand and the PR 4-12 cultures on the other hand, and (2) the proportion of $\mathrm{W}+\mathrm{F}$ cultures that are classified as resistant should be small, as pyrazinamide has hardly been used in Madras city.

Definitions of resistance based on MICs for different suspensions : Several definitions of resistance (Table III, column 2) were considered ; their ability to discriminate between the $\mathrm{W}+\mathrm{F}$ cultures and the PR 4-12 cultures was measured by the difference between the two groups in the percentage of cultures classified as resistant (last column). The largest differences in percentages, indicating the best discrimination, were obtained by defining resistance as an $\mathrm{S}_{1}$-MIC of $200 \mu \mathrm{g} / \mathrm{ml}$ or more, an $\mathrm{S}_{2}$-MIC of $200 \mu \mathrm{g} / \mathrm{ml}$ or more or an $\mathrm{S}_{3}$-MIC of $50 \mu \mathrm{g} / \mathrm{ml}$ or more. Further, the actual differences observed with the three definitions were approximately equal, being $38 \%, 40 \%$ and. $42 \%$, respectively. However, as the $\mathrm{S}_{1}$-MIC definition classified an unduly high proportion (nearly one-fifth) of the $\mathrm{W}+\mathrm{F}$ cultures as resistant and as the $\mathrm{S}_{3}$-MIC could not be determined for an appreciable proportion of the cultures (about $8 \%$ ), an $\mathrm{S}_{2}-\mathrm{MIC}$ of $200 \mu \mathrm{g} / \mathrm{ml}$ or more was chosen as the most satisfactory MIC definition of resistance.

Definitions of resistance based on proportions resistant to different concentrations : The findings with the proportions resistant to $25 \mu \mathrm{g} / \mathrm{ml}, 50 \mu \mathrm{g} / \mathrm{ml}$ and $100 \mu \mathrm{g} / \mathrm{ml}$ pyrazinamide are presented in Table IV, As with the MICs, the W and F cultures had similar distributions, and the amalgamated group $(\mathrm{W}+\mathrm{F})$ was less sensitive than the British cultures and the strain $\mathrm{H} 37 \mathrm{Rv}$; however, the differences were smaller than those obtained with the MICs. Again, PR cultures isolated at 4-6 months and 7-12 months had similar distributions, and the amalgamated group (PR 4-12 cultures) was substantially less sensitive than the $\mathrm{W}+\mathrm{F}$ cultures.

As with the MICs, the findings in $\mathrm{W}+\mathrm{F}$ cultures and PR 4-12 cultures formed the basis for evolving definitions of resistance. Several definitions of resistance (Table IV, column 2) were considered. As the discriminating ability of most of them was of the same order, the final choice was made by selecting that definition which yielded a $5 \%$ prevalence of resistance in $\mathrm{W}+\mathrm{F}$ cultures (it will be recalled that the corresponding proportion was $8 \%$ with the $\mathrm{S}_{2}$-MIC definition). The definitions thus chosen were $(a)$ proportion of $20 \%$ or more on $25 \mu \mathrm{g} / \mathrm{ml},(b)$ proportion of $5 \%$ or more on $50 \mu \mathrm{g} / \mathrm{ml}$ 
Table IV. Cumulative distributions of cultures according to proportions resistant at 40 days

\begin{tabular}{|c|c|c|c|c|c|c|c|c|c|c|c|}
\hline \multirow{2}{*}{$\begin{array}{l}\text { Concentration of } \\
\text { pyrazinamide }\end{array}$} & \multirow{2}{*}{$\begin{array}{l}\text { Proportion } \\
\text { resistant }\end{array}$} & \multicolumn{5}{|c|}{ No chemotherapy with pyrazinamide } & \multicolumn{4}{|c|}{$\begin{array}{l}\text { Duration (months) of chemotherapy } \\
\text { with pyrazinamide } \\
\text { (PR cultures) }\end{array}$} & \multirow{2}{*}{$\begin{array}{l}\text { Measure of } \\
\text { discrimination } \\
\quad(b-a)\end{array}$} \\
\hline & & $\begin{array}{c}\mathrm{H} 37 \mathrm{RV} \\
(\%)\end{array}$ & $\begin{array}{l}\text { British } \\
(\%)\end{array}$ & $\begin{array}{l}\mathrm{W} \\
(\%)\end{array}$ & $\begin{array}{c}\mathrm{F} \\
(\%)\end{array}$ & $\begin{array}{l}\mathrm{W}+\underset{(\%)}{\mathrm{F}} \\
\text { (a) }\end{array}$ & $\begin{array}{l}1-3 \\
(\%)\end{array}$ & $\begin{array}{l}4-6 \\
(\%)\end{array}$ & $\begin{array}{r}7--12 \\
(\%)\end{array}$ & $\begin{array}{c}4-12 \\
(\%)(b)\end{array}$ & \\
\hline \multirow[t]{2}{*}{$25 \mu \mathrm{g} / \mathrm{ml}$} & $\begin{array}{r}1 \% \text { or more } \\
5 \% \text { or more } \\
10 \% \text { or more } \\
20 \% \text { or more } \\
50 \% \text { or more }\end{array}$ & $\begin{array}{r}15 \\
2 \\
0 \\
0 \\
0\end{array}$ & $\begin{array}{r}10 \\
5 \\
0 \\
0 \\
0\end{array}$ & $\begin{array}{r}25 \\
11 \\
8 \\
5 \\
1\end{array}$ & $\begin{array}{r}27 \\
8 \\
8 \\
4 \\
4\end{array}$ & $\begin{array}{r}25 \\
10 \\
8 \\
5 \\
1\end{array}$ & $\begin{array}{r}28 \\
17 \\
11 \\
8 \\
6\end{array}$ & $\begin{array}{l}71 \\
55 \\
51 \\
43 \\
33\end{array}$ & $\begin{array}{l}64 \\
56 \\
52 \\
48 \\
44\end{array}$ & $\begin{array}{l}67 \\
55 \\
51 \\
46 \\
39\end{array}$ & $\begin{array}{l}42 \\
45 \\
43 \\
41 \\
38\end{array}$ \\
\hline & No. of cultures & 85 & 21 & 220 & 48 & 268 & 53 & 51 & 50 & 101 & \\
\hline \multirow[t]{2}{*}{$50 \mu \mathrm{g} / \mathrm{ml}$} & $\begin{array}{r}0.1 \% \text { or more } \\
1 \% \text { or more } \\
5 \% \text { or more } \\
10 \% \text { or more } \\
20 \% \text { or more }\end{array}$ & $\begin{array}{r}32 \\
5 \\
1 \\
0 \\
0\end{array}$ & $\begin{array}{r}38 \\
5 \\
0 \\
0 \\
0\end{array}$ & $\begin{array}{r}37 \\
12 \\
5 \\
3 \\
1\end{array}$ & $\begin{array}{r}36 \\
15 \\
2 \\
2 \\
0\end{array}$ & $\begin{array}{r}37 \\
12 \\
5 \\
3 \\
1\end{array}$ & $\begin{array}{r}40 \\
17 \\
9 \\
6 \\
6\end{array}$ & $\begin{array}{l}78 \\
52 \\
48 \\
46 \\
38\end{array}$ & $\begin{array}{l}68 \\
52 \\
48 \\
48 \\
46\end{array}$ & $\begin{array}{l}73 \\
52 \\
48 \\
47 \\
42\end{array}$ & $\begin{array}{l}36 \\
40 \\
43 \\
44 \\
41\end{array}$ \\
\hline & No. of cultures & 82 & 21 & 219 & 47 & 266 & 53 & so & so & 100 & \\
\hline \multirow[t]{2}{*}{$100 \mu \mathrm{g} / \mathrm{ml}$} & $\begin{array}{r}0.1 \% \text { or more } \\
0.5 \% \text { or more } \\
1 \% \text { or more } \\
5 \% \text { or more } \\
10 \% \text { or more }\end{array}$ & $\begin{array}{r}14 \\
3 \\
3 \\
1 \\
1\end{array}$ & $\begin{array}{l}7 \\
0 \\
0 \\
0 \\
0\end{array}$ & $\begin{array}{r}18 \\
7 \\
5 \\
2 \\
1\end{array}$ & $\begin{array}{r}18 \\
2 \\
2 \\
2 \\
2\end{array}$ & $\begin{array}{r}18 \\
6 \\
5 \\
2 \\
1\end{array}$ & $\begin{array}{r}29 \\
12 \\
8 \\
8 \\
6\end{array}$ & $\begin{array}{l}62 \\
53 \\
51 \\
42 \\
36\end{array}$ & $\begin{array}{l}57 \\
53 \\
49 \\
47 \\
45\end{array}$ & $\begin{array}{l}60 \\
53 \\
50 \\
45 \\
40\end{array}$ & $\begin{array}{l}42 \\
47 \\
45 \\
43 \\
39\end{array}$ \\
\hline & No. of cultures & 78 & 15 & 212 & 44 & 256 & 51 & 45 & 47 & 92 & \\
\hline
\end{tabular}


and (c) proportion of $1 \%$ or more in $100 \mu \mathrm{g} / \mathrm{ml}$. The proportion resistant to $100 \mu \mathrm{g} / \mathrm{ml}$ could not be determined exactly for about $8 \%$ of the cultures; however, most of these had values of less than $1 \%$ and could therefore be classified as sensitive.

The findings with $12.5 \mu \mathrm{g} / \mathrm{ml}$ pyrazinamide have not been tabulated here as definitions based on them did not discriminate very efficiently between the $\mathrm{W}+\mathrm{F}$ cultures and PR 4-12 cultures ; thus, the maximum discrimination obtained was about $30 \%$, which is substantially less than the discrimination of 41-45\% obtained with the definitions based on the tidings with 25,50 and $100 \mu \mathrm{g} / \mathrm{ml}$ pyrazinamide.

Efficiency of the four chosen definitions of resistance : Table $V$ summarises the efficiency of the four chosen definitions of resistance. First, it will be noted that the percentage of $\mathrm{W}+\mathrm{F}$ cultures classified as resistant is uniformly small, namely 5-8 \% Secondly, the discriminating ability of the four definitions appears to be fairly similar ; thus, the difference between the $\mathrm{W}+\mathrm{F}$ cultures and PR 4-12 cultures in the proportion of cultures classified as resistant was $40 \%$ with the $\mathrm{S}_{2}$-MIC definition and $41 \%, 43 \%$ and $45 \%$ respectively, with the definitions based on the proportion resistant to $25 \mu \mathrm{g} / \mathrm{ml}$, $50 \mu \mathrm{g} / \mathrm{ml}$ and $100 \mu \mathrm{g} / \mathrm{ml}$ pyrazinamide.

Table V. Efficiency of chosen definitions of resistance

\begin{tabular}{|c|c|c|c|c|}
\hline & & \multicolumn{2}{|c|}{$\begin{array}{l}\text { Percentage classified } \\
\text { as resistant }\end{array}$} & \multirow{2}{*}{$\begin{array}{l}\text { Measure of } \\
\text { discrimination } \\
\qquad(b-a)\end{array}$} \\
\hline \multicolumn{2}{|c|}{ Definition of resistance } & $W+F$ & PR 4-12 & \\
\hline $\begin{array}{l}\text { St-MIC (10-colony end-point) } \\
\text { Proportion resistant to } 25 \mu \mathrm{g} / \mathrm{ml} \\
\text { Proportion resistant to } 50 \mu \mathrm{g} / \mathrm{ml} \\
\text { Proportion resistant to } 100 \mu \mathrm{g} / \mathrm{ml}\end{array}$ & $\begin{array}{l}200 \mu \mathrm{g} / \mathrm{ml} \text { or more } \\
20 \% \text { or more } \\
5 \% \text { or more } \\
1 \% \text { or more }\end{array}$ & $\begin{array}{l}8 \\
5 \\
5 \\
5\end{array}$ & $\begin{array}{l}48 \\
46 \\
48 \\
50\end{array}$ & $\begin{array}{l}40 \\
41 \\
43 \\
45\end{array}$ \\
\hline
\end{tabular}

*that is, cultures isolated from Madras patients with no history of treatment with pyrazinamide that is, cultures isolated from Madras patients at 4-12 months after the start of daily treatment with pyrazinamide

Extent of agreement between the findings with the four chosen definitions of resistance :

Table VI studies the extent of agreement between the four chosen definitions of resistance, considered pair by pair, in the classification of PR cultures as sensitive or resistant. In general, the extent of agreement was of a high order, the proportion of cultures having the same classification by both definitions of a pair ranging from $92 \%$ to $99 \%$. Furthermore, the disagreements appeared to be fairly evenly distributed. It may, therefore, be concluded that there is little to choose between the four definitions of resistance.

Association between the viable count on acidified drug-free medium and various measures of sensitivity : Table VII relates the results of pyrazinamide sensitivity tests in $\mathrm{W}+\mathrm{F}$ cultures to the growth on the acidified drug-free medium. An $\mathrm{S}_{2}$-MIC of $200 \mu \mathrm{g} / \mathrm{ml}$ or more (that is, a result classifying the culture as resistant) was obtained for $3 \%$ of 75 
cultures with a viable count of less than $10^{4}, 6 \%$ of 150 cultures with a viable count ranging between $10^{4}$ and $10^{5}$, and $22 \%$ of 40 cultures with a viable count of $10^{5}$ or more, a highly significant trend $(\mathrm{P}<0.001)$. Similarly, highly significant trends $(\mathrm{P}<0.001)$ were obtained with $\mathrm{S}_{2}$-MICs of $100 \mu \mathrm{g} / \mathrm{ml}$ or more and $50 \mu \mathrm{g} / \mathrm{ml}$ or more. It follows that if the $\mathrm{S}_{2}$-MIC is employed as a measure of sensitivity (it will be recalled that definitions of resistance based on the $\mathrm{S}_{1}$-MIC and the $\mathrm{S}_{3}$-MIC were unsatisfactory), high viable counts on the acidified drug-free medium could result in over-estimation of resistance.

Table VI. Extent of agreement between the different definitions of resistance* in the classification of PR cultures $\dagger$ as sensitive or resistant

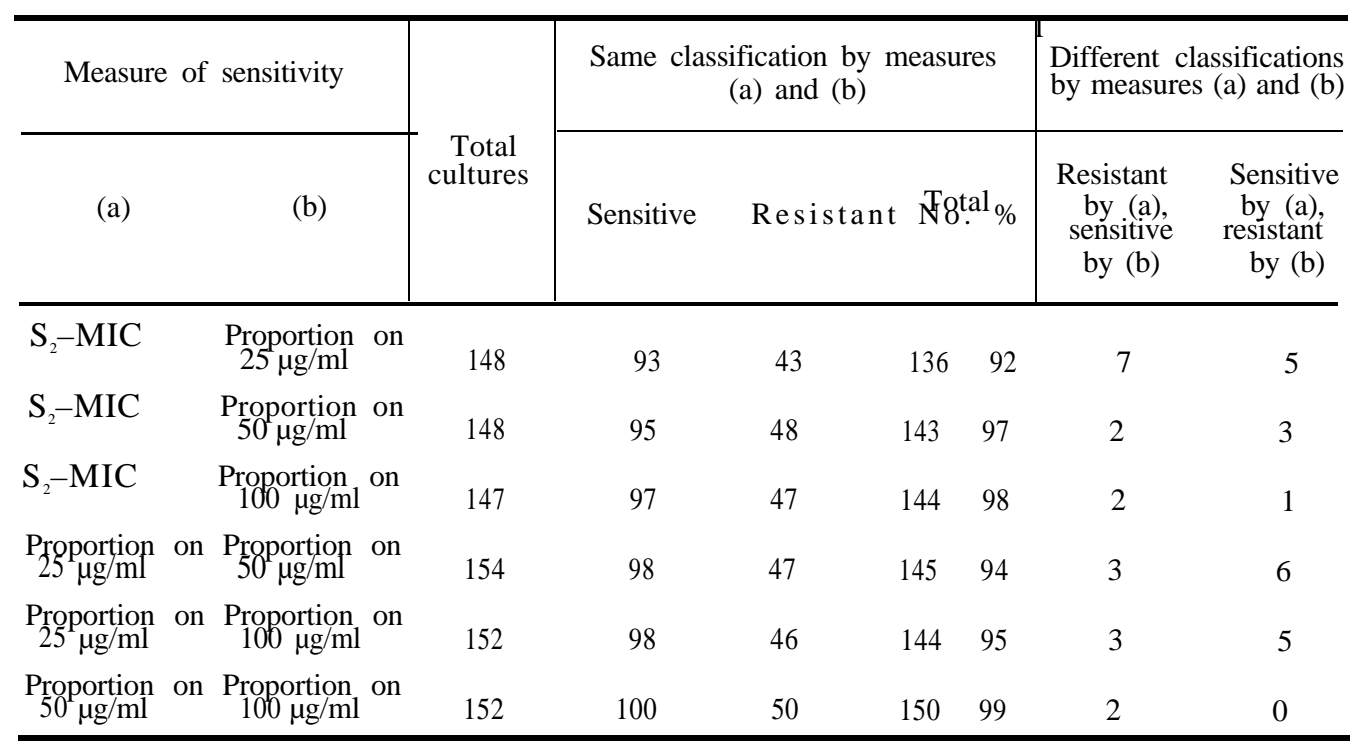

*The definitions were (1) $\mathrm{S}_{2}-\mathrm{MlC}$ of $200 \mu \mathrm{g} / \mathrm{ml}$ or more, (2) growth of $20 \%$ or more on $25 \mu \mathrm{g} / \mathrm{ml}$, (3) growth of $5 \%$ or more on $50 \mu \mathrm{g} / \mathrm{ml}$ and (4) growth of $1 \%$ or more on $100 \mu \mathrm{g} / \mathrm{ml}$

$\dagger$ That is, cultures isolated from Madras patients at 1-12 months after the start of daily treatment with pyrazinamide

In contrast, there was no evidence of an association between the viable count and the proportions resistant to $25 \mu \mathrm{g} / \mathrm{ml}$ (Table VII, right half), $50 \mu \mathrm{g} / \mathrm{ml}$ and $100 \mu \mathrm{g} / \mathrm{ml}$ (analyses not tabulated here).

Findings with duplicate cultures from the same patient : Table VIII examines the correlation between the $\mathrm{S}_{2}$-MIC results of duplicate $\mathrm{W}$ cultures from the same patient. First, it will be noted that the same result was obtained with the duplicate culture for $162(80 \%)$ of 203 patients (this proportion is likely to be an over-estimate as three categories, namely MICs of 12.5, 25 and $50 \mu \mathrm{g} / \mathrm{ml}$, have been amalgamated). Secondly, an MIC of $50 \mu \mathrm{g} / \mathrm{ml}$ or less was obtained with the second culture for 152 (90\%) of 169 patients who had an MIC of $50 \mu \mathrm{g} / \mathrm{ml}$ or less with the first culture, as compared with 
only $17(50 \%)$ of 34 patients who had an MIC of $100 \mu \mathrm{g} / \mathrm{ml}$ or more with the first culture $(\mathrm{P}<0.001)$. This finding suggests that there were consistent differences between the patients in the sensitivity of their organisms to pyrazinamide. The findings with the proportion resistant to $100 \mu \mathrm{g} / \mathrm{ml}$ confirm this inference, (Table IX). Thus, of 156 patients who had a proportion of less than $0.1 \%$ in the first culture, $131(87 \%)$ had a proportion of less than $0.1 \%$ in the second culture ; the corresponding values were $67 \%$ for 24 patients who had $0.1 \%$ to $1 \%$ resistant bacilli in the first culture, and $50 \%$ for 10 patients who had $1 \%$ or more resistant bacilli in the first culture. The trend in these percentages is highly significant $(\mathrm{P}<0.01)$. Significant trends $\left(\mathrm{P}<10^{-5}\right)$ were also obtained with the findings on $25 \mu \mathrm{g} / \mathrm{ml}$ and $50 \mu \mathrm{g} / \mathrm{ml}$ (analyses not tabulated here).

Table VII. Results in W+P cultures* related to growth on acidified drug-free medium

\begin{tabular}{|c|c|c|c|c|c|c|c|c|c|}
\hline \multirow{3}{*}{$\begin{array}{l}\text { Viable count on } \\
\text { acidified drug-free } \\
\text { medium } \dagger\end{array}$} & \multirow{3}{*}{$\begin{array}{c}\text { Total } \\
\text { cultures }\end{array}$} & \multicolumn{8}{|c|}{ Percentage of cultures } \\
\hline & & \multicolumn{4}{|c|}{$S_{2}-\operatorname{MIC}(\mu \mathrm{g} / \mathrm{ml})$} & \multicolumn{4}{|c|}{ Proportion resistant to $25 \mu \mathrm{g} / \mathrm{ml}$} \\
\hline & & $\begin{array}{c}25 \text { or } \\
\text { less }\end{array}$ & 50 & 100 & $\begin{array}{l}200 \text { or } \\
\text { more }\end{array}$ & $\begin{array}{c}\text { Less than } \\
1 \%\end{array}$ & $1 \%-$ & $5 \%-$ & $\begin{array}{c}20 \% \text { or } \\
\text { more }\end{array}$ \\
\hline $\begin{array}{l}\text { Less than } 104 \\
10^{4}- \\
10^{5} \text { or more }\end{array}$ & $\begin{array}{r}75 \\
150 \\
40\end{array}$ & $\begin{array}{l}84 \\
61 \\
52\end{array}$ & $\begin{array}{l}11 \\
23 \\
12\end{array}$ & $\begin{array}{r}3 \\
11 \\
12\end{array}$ & $\begin{array}{l}3^{3} \\
22\end{array}$ & $\begin{array}{l}72 \\
74 \\
82\end{array}$ & $\begin{array}{l}17 \\
15 \\
5\end{array}$ & $\begin{array}{l}3 \\
7 \\
5\end{array}$ & $\begin{array}{l}8 \\
3 \\
8\end{array}$ \\
\hline
\end{tabular}

*that is, cultures isolated from Madras patients with no history of treatment with pyrazinamide $\dagger$ Estimated for the slope inoculated with the standard suspension $\left(\mathbf{S}_{1}\right)$

Table VIII. Correlation between results of duplicate W cultures* from the same patient ( $\mathrm{S}_{2}$-MIC).

\begin{tabular}{|c|c|c|c|c|}
\hline \multirow{2}{*}{$\begin{array}{l}\text { MIC }(\mu \mathrm{g} / \mathrm{ml}) \text { of } \\
\text { first culture }\end{array}$} & \multicolumn{3}{|c|}{ MIC $(\mu \mathrm{g} / \mathrm{ml})$ of second culture } & \multirow{2}{*}{$\begin{array}{c}\text { Total } \\
\text { patients }\end{array}$} \\
\hline & 50 or less & 100 & 200 or more & \\
\hline $\begin{array}{l}50 \text { or less } \\
100 \\
200 \text { or more }\end{array}$ & $\begin{array}{r}152 \\
8 \\
9\end{array}$ & $\begin{array}{r}12 \\
5 \\
5\end{array}$ & $\begin{array}{l}5 \\
2 \\
5\end{array}$ & $\begin{array}{r}169 \\
15 \\
19\end{array}$ \\
\hline Total patients & 169 & 22 & 12 & 203 \\
\hline
\end{tabular}

Of 19 patients whose first culture was classified as resistant by the $\mathrm{S}_{2}$-MIC definition (namely, $200 \mu \mathrm{g} / \mathrm{ml}$ or more), only $5 \mathrm{had}$ the second culture also classified as resistant by same definition. (Table VIII). The corresponding proportion was 4 of 10 , 
when resistance was defined as $1 \%$ or more growth on $100 \mu \mathrm{g} / \mathrm{ml}$ (Table IX). Thus, the proportion of patients who had both cultures resistant was small, namely 5 of 203 with the MIC definition and 4 of 190 with the proportion definition. It may, therefore, be concluded that wild strains with consistent resistance to pyrazinamide did not constitute more than $2-3 \%$ of all wild strains.

Table IX. Correlation between results of duplicate $W$ cultures* from the same patient (Proportion resistant to $100 \mu \mathrm{g} / \mathrm{ml}$ )

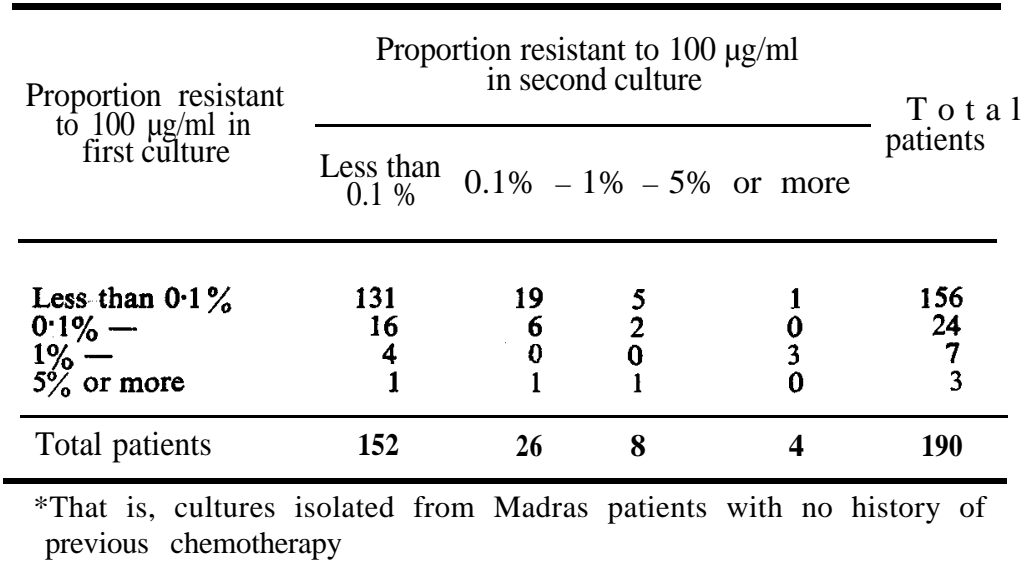

Emergence of resistance during treatment with a daily regimen containing pyrazinamide : The pattern of month-by-month sensitivity test results was examined for 10 patients who repeatedly produced positive cultures during treatment at this centre with a daily regimen containing pyrazinamide (PR cultures). Two measures of sensitivity, namely, the $\mathrm{S}_{2}$-MIC and the proportion to $100 \mu \mathrm{g} / \mathrm{ml}$, were considered (data not tabulated here).

In six patients, resistance to pyrazinamide emerged at 4, 4, 5, 5, 5 and 7 months, respectively, by both criteria, namely, $\mathrm{S}_{2}-\mathrm{MTC}$ of $200 \mu \mathrm{g} / \mathrm{ml}$ or more and $1 \%$ or more growth on $100 \mu \mathrm{g} / \mathrm{ml}$; further, all subsequent cultures were resistant by both the definitions.

In one patient, all the cultures isolated at 1-11 months were sensitive by both definitions; at 12 months, however, the culture was resistant by the proportion definition ( $41 \%$ ) but sensitive by the MIC definition $(25 \mu \mathrm{g} / \mathrm{ml})$. In the remaining three patients, there was no evidence, either from the MICs or from the proportions resistant, that resistance to pyrazinamide had emerged. None of the above four patients was very regular in taking drugs.

\section{Discussion}

Routine determinations of pyrazinamide sensitivity have proved to be difficult in many laboratories on account of the failure of a proportion of strains of M. tuberculosis 
to grow in a medium whose $\mathrm{pH}$ is sufficiently acidic for the activity of the drug to be demonstrated. The acidified Lowenstein-Jensen medium used in the laboratory was, however, found to sustain the growth of all but 4 of the 538 strains tested. A great deal of care was exercised in the preparation of this medium. In particular, a $\mathrm{pH}$ meter with a glass electrode was used to adjust the $\mathrm{pH}$. Next, the inoculum was evenly distributed over the surface of the soft acid medium, as experience showed that, on drug-containing slopes, a cluster of small colonies often developed in any area where the inoculum was locally dense, presumably because the concentration of bacterial pyrazinamidase in such areas was so high that it destroyed the pyrazinamide and made the medium more alkaline. Finally, the slopes were incubated at $37^{\circ} \mathrm{C}$ for 40 days ; even so, some strains produced minute colonies which were rather difficult to distinguish from the medium. In the light of these remarks, it may be concluded that pyrazinamide sensitivity tests should be undertaken only in specialized laboratories.

The results of the sensitivity test were expressed as minimal inhibitory concentrations (MICs) for various sizes of the inoculum and as proportions resistant to various concentrations of pyrazinamide. For each of these measures, the findings in a population consisting predominantly of sensitive cultures (obtained from patients with no history of chemotherapy with pyrazinamide) were compared with those in a population consisting of cultures obtained 4-12 months after the start of daily treatment with the drug; a definition of resistance was then chosen such that it discriminated efficiently between the two populations and, furthermore, classified only a small proportion of the former population (predominantly sensitive) as resistant.

Considering first the various MIC measures, the MIC (10-colony end-point) with a 1 in 10 dilution of the standard inoculum employed at this Centre provided the most satisfactory definition of resistance, namely $200 \mu \mathrm{g} / \mathrm{ml}$ or more. Next, there was little to choose between the proportion definitions, the optimal definitions being $20 \%$ or more on $25 \mu \mathrm{g} / \mathrm{ml}, 5 \%$ or more on $50 \mu \mathrm{g} / \mathrm{ml}$ and $1 \%$ or more on $100 \mu \mathrm{g} / \mathrm{ml}$. The definitions recommended by Canetti, Rist and Grosset (1963) are $50 \%$ or more on $20 \mu \mathrm{g} / \mathrm{ml}$ and $10 \%$ or more on $100 \mu \mathrm{g} / \mathrm{ml}$, employing a 40-day incubation period ; however, the $\mathrm{pH}$ of their Lowenstein-Jensen medium was 5.0 before inspissation, as compared to 4.80-4.85 in the present study. Novak, Feitova and Sytarova (1970) have suggested a proportion definition of $50 \%$ or more on $100 \mu \mathrm{g} / \mathrm{ml}$, employing a 4-week incubation period and Lowenstein-Jensen medium with a pre-inspissation $\mathrm{pH}$ of 5.27.

The efficiency of the four Madras definitions of resistance was of the same order, each definition classifying as resistant 5-8\% of the predominantly sensitive group of cultures and 46-50\% of the group of cultures obtained 4-12 months after the start of daily treatment with pyrazinamide. Furthermore, highly satisfactory agreement, namely 92-99\%, was obtained between pairs of definitions in the classification of individual cultures as sensitive or resistant. Nevertheless, there would appear to be a slight advantage in employing the proportion definitions as the findings were not influenced by the viable count on the drug-free acid medium, whereas larger viable counts were associated with higher MICs. This advantage is, however, offset by the practical 
difficulties in undertaking a more complex test, involving serial dilutions of the inoculum and the counting of colonies which are sometimes minute.

In patients with no history of previous chemotherapy, a finding of pyrazinamide resistance in one culture was often not confirmed by the finding in a second culture ; this suggests, that a single resistant result pretreatment does not always reflect the true sensitivity of the strain. In a study of reserve regimens in East Africa (East African/ British Medical Research Council Pyrazinamide Investigation 1969), pyrazinamide sensitivity tests were set up in a very similar manner to those in the present study. No association was found between the pretreatment sensitivity of the strains, as measured by MICs or proportions resistant, and the response to treatment with regimens of streptomycin plus pyrazinamide. Therefore, in patients with no history of chemotherapy with pyrazinamide, a finding of pyrazinamide resistance in a single pretreatment culture should not be regarded as a contra-indication for treatment with this drug.

Considering next the cultures isolated from patients during daily treatment with pyrazinamide, resistance was found in 8-9\% of the cultures obtained in the first 3 months, $43-52 \%$ of those obtained at 4-6 months, and 44-49\% of those obtained at 7-12 months (Tables III and IV). These findings indicate that resistance to pyrazinamide usually emerged between 4 and 6 months after the start of treatment. This was confirmed by an examination of the month-by-month sensitivity test results for 10 patients who were repeatedly culture-positive during treatment.

British cultures were appreciably more sensitive to pyrazinamide than Madras cultures, when sensitivity to the drug was measured as an MIC; however, when it was measured as the proportion resistant to different drug concentrations, the differences were not so appreciable: This may be explained by the fact that colony counts on drug-free acidified medium were substantially lower for the British cultures than for the Madras cultures, and the finding that low counts on drug-free acidified medium were associated with low MICs but had little effect on the proportions resistant. Finally, the difference between British and Madras strains in their ability to grow on drug-free acidified medium may be due to the fact that the former were maintained by repeated sub-cultivation on normal Lowenstein-Jensen medium while the latter were primary isolates ; it is also possible that the $\mathrm{pH}$ of 4.80-4.85, which was found to be the best for Madras strains, may not be optimal for all strains.

\section{References}

Canetti, G. Rist, N. and Grosset, J. 1963. Measure de la sensibilite du bacille tuberculeux aux drogues antibacillaires par la methode des proportions. Revue Tuberc Pneumol 27, 217.

Cruickshank, R. 1965. Medical Microbiology, 11th ed 753. E. \& S. Livingstone, Edinburgh and London.

East African/British Medical Research Council Pyrazinamide Investigation. 1969. A controlled comparison of four regimens of streptomycin plus pyrazinamide in the retreatment of pulmonary tuberculosis. Tubercle London 50, 81.

Kushner, S. Dalalian, H. Sanjurjo, J.L. Bach, F.L. (Jr.) Safir, S.R. Smith, V.K. and Williams, J.H. 1952. Experimental chemotherapy of tuberculosis. II. The synthesis of pyrazinamide and related compounds. J Amer Chem Soc 74, 3617. 
McDermott, W. and Tompsett, R. 1954. Activation of pyrazinamide and nicotinamide in acidic environments in vitro. Amex Rev Tuberc 70, 748.

Malone, L. Schurr, A. Lindh, H. McKenzie, D. Kiser, J.S. and Williams, J.H. 1952. The effect of pyrazinamide (aldinamide) on expertmental tuberculosis in mice. Amer Rev Tuberc 65, 511.

Marks, J. 1964. A 'stepped $\mathrm{pH}$ ' technique for the estimation of pyrazinamide sensitivity. Tubercle, London 45, 47.

Miller, A.B. Tall, R. Fox, W. Lefford, M.J. and Mitchison, D.A. 1966. Primary drug resistance in pulmonary tuberculosis in Great Britain : Second National survey, 1963. Tubercle London 47,92

Novak, M. Feitova, S. and Sytarova, J. 1970. Urocovani ceitlivosti a rezistence M. tuberculosis Proti Pyrazinamidu. Druhe Sdeleni : Rust kmenu M. tuberculosis a antibakterialni ucinek pyrizinamidu na modifikovane kysele pude Lowenstein-Jensanove. Kriterium rezistence proti PZA. Stud Pneumol Phtiseol Cecboslov (Rezhl Tuberk) 30, 3-4, 140.

Schwartz, W.S. and Moyer R.E. 1954. The chemotherapy of pulmonary tuberculosis with pyrazinamide used alone and in combination with streptomycin, para-aminosalicylic acid or isoniazid. Amer Rev Tuberc 70, 413.

Steenken, W. and Wolinsky, E. 1954. The antituberculous activity of pyrazinamide in vitro and in the guinea-pig. Amer Rev Tuberc 70, 367.

Stottmeier, K.D. Beam, R.E. and Kubica, G.P. 1967. Determination of drug susceptibility of mycobacteria to pyrazinamide in 7H10 agar. Amer Rev Resp Dis 96, 1072.

Tarshis, M.S. and Weed, W.A. 1953. Lack of significant in vitro sensitivity of mycobacterium tuberculosis to pyrazinamide on three different solid media. Amer Rev Tuberc 67, 391.

Tripathy, S.P. 1966. Sensitivity test for pyrazinamide. In : Proceedings of the 21 st Tuberculosis and Chest Diseases Workers Conference, held February 11-14th, 1966 at Calcutta p. 272, Tuberculosis Association of India, New Delhi.

Tuberculosis Chemotherapy Centre, Madras. 1959. A concurrent comparison of home and sanatorium treatment of pulmonary tuberculosis in South India. Bull WHO 21, 51.

United States Veterans Administration. 1960. Tuberculosis Laboratory Methods-Veterans Abministration, Department of Medicine and Surgery, Central Office, WMethods 25, D.C. 